\title{
RADICAL ISLAMIC IDEOLOGY IN MAKASSAR From Dissemination to Politicization
}

\author{
Mustari Mustafa \\ UIN Alauddin, Makassar - Indonesia
}

\begin{abstract}
This paper is concerned with exploring the dissemination and politization of radical Islamic ideology in Makassar. Little has been done to study this important issue. How did radical ideology develop from time to time in Makassar and how has it evolved to become the political power in the region have gone unnoticed. This paper tries to fill this gap. It assumes that radical ideology is a form of discourse, going through a paradigmatic test in which it was criticized, deconstructed, constructed and reconstructed. The paper is part of the attempts to deconstruct radical ideology by means of dismantling two main factors that have caused it to flourish, the actors and organizations of the ideology. A particular attention is give to the following two issues, in what way the ideology may be regarded as a discourse, and how this discourse is being translated into an ideology. These two specific problems becomes the centre of the analysis together with the process in which they intermingle.
\end{abstract}

Keywords: Politics, radical, ideology, Islam, Shari' ${ }^{6} a h$

\section{Introduction}

Since the occurrence of the transnationalization of the networking of socio-politics among the developing nations, there is a phenomenon of the moving of the impact of ideologies such as radicalism, fundamentalism, liberalism, pluralism and many others which gradually change the life of people. Along with the emergence of the ideologies the so called two ideologies namely radical and moderate, the actors and organizations that support these ideologies emerge and even become the driving force to propagate these ideologies conspicuously. 
Specifically, this research chooses the group of radical Islamic movements to be the focus of research. The latest development observed, particularly since the life of Indonesian nation entered the second decade of its reformation, the supporters of radical Islamic movements have realized that they enter the battle of idea to propagate to Islamic community that the thought they support is the only true interpretation about Islam. They understand Islam in a monolithic way and tend to refuse other Islamic variants which they consider have deviated from the true Islam.

Generally, the main strategy of these movements is to form and support the local groups that function as an agent of spreading their ideology. In addition to that, they also try to marginalize more tolerant Islamic understandings which have been existing and dominant in many parts of Indonesia. In so doing, they struggle to infiltrate to the variety sectors of society either by peaceful way or even by violent way. This method have been widely known in the history of the spread of every religion, particularly the religions which when they were revealed and introduced to society touch the people civilization often caused the conflict. The conflict in society's life often ended up with the clash among the adherents of those religions. Two of the causes worth mentioning here are the truth claim and the vested interest of every group using the name of religion. Thus, religion is often being used as the tool to justify or to support its claim. Presently, what we are witnessing is the ambiguity between the universal message of religion and the attitudes shown by the society either in the context of a nation or as in the context of transnational and the global life. Often, we see the emergence of violence acts on the name of religion or moral message, but have their impacts on people's life such as the loss of property, fear, anxiety, or hatred to other which eventually give unsecured condition to many groups.

As a result of those attitudes is the emergence of negative and destructive and even unproportional expression such as "we as a nation" is understood as we as one region, race, group, or one political affiliation, not as people of nation being bounded by the sentiment of one big region, that is the region spanning from Sabang to Merauke. The case also often happened in our solidarity as Muslim, which often emerges for the case of Palestine by conducting rallying demonstration without seeing the actual condition of the conflict. It is worth noting that the demonstration often troubles others. 
In some places like Saudi Arabia, Sudan, Gaza, Afghanistan and area of Pashtun- Pakistan, the supporters of radical Islamic movements have succeeded to enforce their ideologies. Meanwhile, in many parts of Muslim world, there is hardly a serious effort to uncover the radical Islamic movements, nor a serious effort to uncover the mobilization of supports for the tolerant and pluralistic views movements and in line with the modern world, whereas most of the world society wants the harmony in global life without questioning the differences. In Indonesia, this reality has been identified by some of Indonesian figures, so that the spiritual life of Islam is still strong. In relation to this, some of Indonesian Islamic figures realized that there is threat from the radical Islamic movements and are ready to anticipate it. ${ }^{1}$

Nevertheless, the reaction of the moderate groups as well as the Muslim scholars' and national figures toward these radical Islamic movements is actually indicating the strengthening of the influence and the infiltration of these groups in Indonesia lately. Meanwhile, at the same time, this reaction can initiate the effort to block and dismantle the activities of the radical Islamic movements publicly. ${ }^{2}$

\section{Religion: Between Ideology and Reality}

If the existence of religion should be defended by mean of violence, so what are the contributions of religion to the human civilization? If the symbols and formal practices of religion become the main measurement of piety, then when will the religion able to take its adherents to depth meaning of life and the acceptance of plurality? If the sectarianism becomes the pillar of religious identity for its adherent, how could religion build more just social institutions? Some religious aspects being uncovered through those questions are subtle to the violence acts. New awareness for the deep understanding of religious teaching and practice should be promoted, so that the religion itself is not treated as the basic of ideology and justification for the violence acts. Religion itself often emerges with the two ambiguous faces. ${ }^{3}$ On one hand, religion becomes the place where people find the peace, the depth meaning of life, and the firm hope. In religion, many

\footnotetext{
1 Abdurrahman Wahid (ed.), Ilusi Negara Islam (Jakarta: The Wahid Institute in Cooperation with Gerakan Bhineka Tunggal Ika, 2009), p. 44.

2 Ibid.

${ }^{3}$ Haryatmoko, Etika Politik dan Kekuasaan (Jakarta: Penerbit Kompas, n. d.), p. 62.
} 
people and groups take the strength and get the pillars to face with the misery, oppression or totalitarian regime. On the other hand, religion is often related to the violence phenomenon, particularly, in Indonesian cases lately. The defense tends to say that religion teaches peace and against violence but it is the man who abuse it for the self or group interest that finally fuelled the violence acts.

Actually, religion is supposed to be understood outwardly and inwardly since the outward understanding will cause the lost of the religious spirit. In contrast, a mere inward understanding of religion will cause discontinuation of the socio-historical message of the religion itself. If the religion suggests its adherent to respect and appreciate the people, the reality is often contradicted to it. We ourselves witness and the history notes that the religion has considerable contribution to fuel the hatred and suspicion drive misunderstanding and lead to the conflict.

The defense often emerged is that religion is not the main trigger of the conflict. Many observers and religious leaders accused economic discrepancy, the political rivalry or social jealousy. However, the problem is, why the religion is unconsidered as a trigger of such conflict, giving an ideological base and symbolic justification. The justification is not only functioned to lighten or to give an alibi of personal responsibility but even strengthen the will, sharpen the enmity and mystify the conflict motive to be the struggle for defending the faith and the truth, or in sum for the sake of God.

By the mystification of motive, the conflict changes its shape to be the struggle for human's existence. Every compromised effort will be considered to be the weakening or the betrayal. In this case, the irrationality emerges in the form of mingling the personal interest or the groups with the will of the so called God. The will of God will be understood directly in the human's incapability. The claim that religion often teaches good things is intrinsically true, but is the adherent of religion realized that there will be a gap between religious teachings and their practices in the real life.

The belief and teaching did not automatically become the system of action. ${ }^{4}$ It is even very easily justifies the violence acts. The concrete religion is the religion understood and practiced by its adherents through the moral norms, institution, ritual, and symbol. To

${ }^{4}$ Ibid., p.64 
understand religion in a concrete way will take people to be aware of the mechanism of violence. This also will take to the process of purity in order that religion could help its adherents to seek for the depth meaning of life and contribute the civilization that respect humanity.

In Islam, every Muslim believes that God being worshipped is the Omnipotent. There is no even one single thing escaped from His Knowledge, His power and His merciful (Q. 20: 5). ${ }^{5}$ With his power, God could make all humankind to be one religious community but $\mathrm{He}$ did not do that and let His creatures to believe in it or to reject it (Q. 18: 29). It is for the benefits of mankind that through His messengers He teaches good things and bad things, lawful and unlawful, truth and false to get closer to God. In this matter, the prophet taught Muslims to perform good deeds in order that he loves his community. ${ }^{6}$

The understanding and religiousness of radical groups differs distinctively from the understanding and religiousness of moderate Muslim community. On the one hand, as a result of rigid, literal, narrow and limited understanding toward Islamic teachings, radical groups emphasize the outward religiosity and neglect inward aspect of religiosity. ${ }^{7}$ Symbol, identity and the spirit, for them are more important than substantive awareness, socio-historical events as well as the quality of religious practice. Therefore, they are eager to enforce their understanding on Islam to anyone through the formalization and the implementation of Islamic law, and establish the Islamic Shari'ah or Islamic caliphate. ${ }^{8}$

It seems they assume that God will satisfy if there is a political power or the ruler who rules on behalf of God. They imagine that God Almighty will be happy if the Islamic law with their version becomes

\footnotetext{
${ }^{5}$ In the exegetical tradition, especially those who applied esoteric exegesis (Tafsr bi alIsyara $\bar{a}$ ) this verse is naturally understood as an the indication that the mercy of God controls His power.

${ }^{6}$ This is called "Hadith Qudsi" (the prophet's sayings but the content is from God) that has been found in many books of hadith and is often quoted by Muslim scholars.

${ }^{7}$ In this conjunction, it is necessary to present that Islamic radical groups generally neglect spirituality, then they often subjectively consider the rituals practiced by the people has deviated from the true teachings of Islam. This phenomenon could be read as the result of their political obsession and worldly power, besides literal orientatation, narrow mindedness and limited horizon in understanding the sources of Islam.

8 This is a result of the interview with a member or management of Wahdah, Hizbut Tahrir and some members of Jamaah Tabligh in Makassar, South Sulawesi.
} 
the positive law or the law of the state. Moreover, unconsciously, some of them are in the opinions that God is powerless and thus needs defender. Perhaps all of these are reason only for their hidden agenda to come to the power. All of these cannot be separated from the ignorance as limited knowledge is dangerous. In addition, the ignorance often makes someone arrogant and refuse the truth because of he is fail to understand it or to feel it. ${ }^{9}$

If the formalization becomes the goal when practicing religion and adhering Islam, then the formality of religion become new God and thus no more way to gain the pleasure of true God. All are theological faults that should be corrected and even opposed when it is spread to other people. Every effort of the formalization of religion is a pure political reason, that is to gain the power. If it is said that it was based on the fact that God manages all aspect of the life, this is obviously theological fault of understanding that should be rejected. It is not the form of state and the formalization of religion required to be a good Muslim but the sincerity of spiritual awareness to realize the presence of God. Thus, the claim to establish Islamic community through the implementation of Shari'ah or build Islamic caliphate is political maneuver to gain the power. ${ }^{10}$

\section{Ideology of Centralistic Totalitarianism}

The ideology of Islamic radical group is centralistic totalitarianism and makes religion as the reference of theological subject. Thus, theological claim they present is actually a certain maneuver as a tool to subjectively assault other groups in the name of shari'ah. ${ }^{11}$ If ideological view of centralistic-totalitarianism applied to the shari'ah it

\footnotetext{
${ }_{9}^{9}$ Wahid, Ilusi Negara, p. 116.

10 The researcher finds this opinion in many individuals of Islamic radical groups in Makassar which basically has the similarities with their network outside Makassar since organizations like Hizbut Tahrir of Indonesia has a global network and relatively has the same concept, agenda and ideology. Wahdah is excluded from this group as it has only a few branch in Makassar. The Committe of the Establishment of Islamic Shari'ah in Indonesia was initiated in South Sulawesi and is lately followed by some other regions.

${ }^{11}$ Literally Shari'ah means "the way of water or river, and it is from which the water will flow naturally to the sea, its origin and goal." With this basic understanding, anybody who follows the true path will reach his or her origin and goal.. See, Ibn Manșūr, Lisān al-'Arab, Vol. VIII (Beirūt: Där al-Ṣāirir, n. d), p. 175.
} 
will bring legalistic consequence, that is centralistic totalitarianism law. This could be confirmed, for example, by the opinion of the activist, in interview, a member of Hizbut Tahrir said: "the members of Hizbut Tahrir struggle for ideological thought and their leader lives in Europe (without willing to mention the identity even the writer has asked him). This phenomenon shows that their coordination and the line of the commandment will give significant impact on their centralistic religious thoughts. ${ }^{12}$ Therefore, law for them should rule all aspect of life without exception and the state controls the understanding of law and its application in life as a whole system. That is why, in this thought, the practice of Shari'ah cannot be separated from the political affairs. This centralistic ideology is very conspicuous in the appearance of Islamic radical groups in general in Indonesia, while in Makassar, there are only certain groups appear, it depends on their characters.

The phenomenon of the politicization of Islamic shari'ah in this research is blatant, for example, the activity of worship has a double goal. Besides for the establishment of Islamic law, it is also the affirmation of their attitude and identity towards the national political issue. The research found that the actors of the Islamic radical movements often used general forum they attend to present their opinions and even debate in that program, and sometimes they make a campaign pointing the importance of the implementation of Islamic law. They consider the collapse we encounter either at level of political leadership or at the level of civil society leadership caused by their ignorance to be a perfect Muslim. Therefore, the implementation of Islamic Shari'ah should be struggled through political line. ${ }^{13}$

Generally, this research found that the need of the establishment of Islamic Shari'ah is more based on the disappointment factor of contemporary socio-political situation of society as a whole rather than the spirit of the true religiosity. Respondents mostly argued that Shari'ah is needed as the appropriate solution for the problem of life. They also argued that the critical situation which Indonesia

\footnotetext{
${ }^{12}$ Interview held in Makassar, and the respondent is the officer calling himself the deputy of secretary.

13 This attitude and stand point are actually contradicted with the reality where they often project themselves to be the supporters of moderate Islam and anti-violence. Whereas, the violence can occur in three aspects, doctrinal, theological, and sociological.
} 
experienced is caused by the development of society and nation under the influence of Western countries. Either capitalism or liberalism has been the references for national building, that is why it finally caused the crisis and for this condition, it is the Shari'ah becomes the best solution.

As Muslim exegetes and scholars believe, Islam is not a separate part of other religions. Islam did not appear as something absolutely new, but it is a complementary, completing and perfecting others and not as an alternative which negates others. Divine sacred texts, however, should be understood as continuity in their nature meaning that the latest version of the holy books did not abrogate the previous ones. ${ }^{14}$ Discussing the universal dimension of Islam meaning discussing the main principles and mission of Islam revealed to the earth. ${ }^{15}$ This basic mission, then preached by some Islamic preachers and scholars and even by the Muslims in general often mention "Islam as the blessing for all" (rahmah li al-alamin). The objectivity of the aforementioned view is contradicted with the reality that Islam is often related to the anarchical acts, intimidation and enforcement of will. This is totally contradicted with the human nature (fitrah) which yearning harmony, moderation, tolerance and balanced in their life. The idealization of the concept and basic mission of Islam which is in accord with the nature strengthens the spirit of Islam as the antidote religion for the solution of moral decadence. On the contrary, the claims based on the enforcement will ignore esoteric and ethical dimension of Islam.

\section{Obsession of the Establishment of Islamic Shari'ah}

As has been known, the idea and aspiration of the establishment of Islamic state in Indonesia has arisen various responses and interpretations in society, either among the Muslims or among the non-Muslims. Some hold the opinion that the issue of Islamic state which is deliberately propagated to discredit some Islamic groups. Some others, however, clearly admit that the idea and aspiration of the

\footnotetext{
14 This is actually one of the meanings of Islam as the blessing for all "rabmatan lil'alamin" for its presence as the complementary but not as negator, let alone the killer. See, Mustari, "Etika Religius Syekh Yusuf Relevansinya dengan Dakwah Islam Di Indonesia," (Unpublished Doctoral Thesis, Faculty of Philosophy, the University of Gadjah Mada, Yogyakarta, 2009), p. 213

${ }^{15}$ Said Aqil Siroj, Tasawuf Sebagai Kritik Sosial (Bandung: Mizan, 2005), p. 16.
} 
establishment of Islamic state lately really exists and will be realized. If we observe closely, the agenda of the movement of the committee for the establishment of Islamic Shari'ah (Komite Penegakan Syariat Islam) in South Sulawesi we will suspect such wish. It is because their jargon to recommend and even press the establishment of Local Legislation (Peraturan Daerab) based on Islamic Shari' ${ }^{\prime}$ ah to gain the pleasure and the bless of God is the fact showing the existence of the great and long term agenda.

The failure or the experimentation of Islamic state in Indonesian history, for them was only a delayed agenda and should always be incited. South Sulawesi, Aceh and some parts of the West Java that begin to accommodate the struggle of these groups become an interesting fact speculating toward the idea of the establishment of Islamic state. Moreover, it is proved that some radical movements of the establishment of Islamic Shari'ah relate themselves with the struggle of Islamic State of Indonesia (Negara Islam Indonesia/NII) or the Islamic State (Darul Islam/DI) and particularly in South Sulawesi, the struggle of the establishment of Islamic Shari'ah is related to the spirit of its former history. ${ }^{16}$

There are some reasons why the demand for the formal implementation of Islamic Shari'ah emerged. One of the most important reasons is that Islam is a complete religion that covers totally all way of life. Thus, Islam should be functioned as the only reference to solve the problem of nation. Furthermore, the demand for the implementation of Islamic law is forced by the strong wish to show the distinctive Islamic identity among the mixing identity in a global world. ${ }^{17}$ In addition, the corruption factor, the absence of guarantee of the certainty of law, vested interests-driven process of judicial court have given the reasons for radical groups to offer an alternative law although the problem lays not in the law itself but in the apparatus.

If it is reviewed sociologically, such reasons will neglect the humanity aspects as the disparity and the plurality of the status and human rights has no place. This is certainly a very weak effort. Islam is a complete religion and should be a reference for all problems of life.

\footnotetext{
16 Taufik Adnan Amal and Samsu Rizal Panggabean, Politik Syari'at Islam, Dari Indonesia bingga Nigeria (Jakarta: Alvabet, 2004), p. 83 and p. 89.

17 Noorhaidi Hasan, Laskar Jihad Islam, Militancy, and the Quest for Identity in Post-New Order Indonesia (Leiden: Utrecht University, The Nederland, 2005), pp.179-180.
} 
It is certain that Muslim mostly have this believe. Even every adherent of religion believes that his or her religion is the complete one. In the case of Islamic Shari'ah, it is worth noting that it has become an integral part of Indonesian Islamic community's life since Islam came to Indonesian Archipelago and thus, it does not necessarily to formally established.

\section{Conclusion}

Directly or indirectly, the ideology and agenda of Islamic radical movements in theological frame or sociological frame are related to their political ideal. That political ideal, in fact related to the political system that has been adhered by the majority of people in the world including Indonesia. Democracy is the system that has been chosen by the Indonesian people since the establishment of this state. Therefore, it should be admitted as the agreement where the rights and duty of the people are to defend and fill it with Indonesian values consisting of the reality of plural society. Challenges and hindrances in the process of being Indonesians should be faced as a collective burden without having the intention to restore it radically, and accomplish all the problems together in the frame of the unitary state of the republic of Indonesia.

There are different characteristics of Islamic radical groups. Some rejected democracy as they see it as contradicted with Islamic teaching, and some accepted it to meet their own purposes. Either the group accepting the democracy or the one rejecting it finally meet at the same goal, that is the legislation of Islamic law. The Islamic radical group which does not accept democracy has based its argument on theological and sociological view. Democracy is considered, particularly, un-Islamic for it does not derive from Islam, and therefore should be replaced by the new system which is more centralistictotalitarian. Their agenda aims at establishing a new democratic system which is used for un-democratic purposes. []

\section{Bibliography}

\section{Books and Articles}

A'la, Abd. "Genealogi Redikalisme Muslim Nusantara: Akar dan Karakter Pemikiran dan Gerakan Padri dalam Persfektif Hubungan Agama dan Politik Kekuasaan." Unpublished paper, IAIN Sunan Ampel Surabaya, 2009. 
Abdullah, Amin. Dinamika Islam Kultural: Pemetaan Atas Wacana Keislaman Kontemporer, Bandung: Mizan, 2000.

Abdullah, Taufik. Islam dan Masyarakat: Pantulan Sejarah Indonesia. Jakarta: LP3ES, 1987.

Abou El Fadl, Khaled. Atas Naman Tuhan: Dari Fikih Otoriter ke Fikih Otoritatif. Jakarta: Serambi, 2003.

-. Selamatkan Islam Dari Muslim Puritan. Transl. Helmi Mustafa. Jakarta: Serambi, 2007.

----------. The Ugly and The Modern Ugly; Reclaiming The Beautiful in Islam 'Progressive Moslem: on Justice, Gender and Pluralism. Oxford: Oxford University Press, 2003.

al-Alwani, Taha Jabir. Krisis Pemikiran Islam Modern. Selangor: The International Institute of Islamic Thought, 1995.

al-Siba'i, Hani. Balanda Jamaah Jihad (translation). Solo: Jazera, 2005.

Alvi, Zainuddin. Islamic Educational Thought in Middle Ages. India: Hederabat, 1983.

Amal, Taufik Adnan and Samsul Rizal Panggabean. Politik Syariat Islam: Dari Indonesia Hingga Nigeria. Jakarta: Alvabet, 2004.

Azra, Azyumardi. Jaringan Ulama: Timur Tengah dan Kepulauan Nusantara Abad XVIII. Bandung: Mizan, 1994.

---------. Reposisi Hubungan Agama dan Negara. Jakarta: Penerbit Buku Kompas, 2002.

Baso, Ahmad et al. Pribumi: Mendialogkan Agama Membaca Realitas. Jakarta: Erlangga, 2000.

Bellah, Robert N. Beyond Belief, Essay on Religion in a Post-Tradisional Word. New York: Harper and Row, 1976.

Boisard, Marcel A. Humanisme Dalam Islam. Jakarta: Bulan Bintang, 1986.

Boulatta, Issa J. Dekontruksi Tradisi: Gelegar Pemikiran Arab Islam. Transl. Imam Khoiri. Yogyakarta: LKIS, 2000.

Bukhari, Imam. Shahih al-Bukhari. Semarang: Toha Putera, 1998.

Departemen Pendidikan dan Kebudayaan RI. Kamus Bahasa Inggris, Cet. II. Jakarta: Balai Pusataka, 1991. 
Esposito, John L. The Islamic Threat: Myth or Reality. Oxford: Oxford University Press, 1992.

Gellner, Ernest. Fundamentalism as a Comparative System: Soviet Marxism and Islamic Fundamentalism Compared. Chicago: University of Chicago Press, 1995.

Halliday, Fredd. "The Politics Of Islamic Fundamentalism: Iran, Tunisia and the Challenge to the Secular State." in Akbar S. Ahmad and Hastings Donnan. Islam, Globalization, and Postmodermity. London: Routletge, 1994.

Hidayat, Komaruddin. Wabyu di Langit Wabyu di Bumi. Jakarta: Paramadina, 2003.

Hizbut Tahrir Indonesia. Selamatkan Indonesia dengan Syariah. Jakarta: HTI Press, 2006.

Hoffman, Valeri J., "Muslim Fundamentalists: Psychosocial Profiles." in Marty and Appleby. Fundamentalism Comprehended. Chicago: University of Chicago Press, 1995.

Imarah, Muhammad. Fundamentalisme dalam Prespektif Barat dan Islam. Yogyakarta: Gema Insani Press, 1999.

Iqbal, Muhammad. The Recontruction of Relegius Thought in Islam. Lahore: Ashraf, 1982.

Junaidi, Abdul Basith et al. Islam dalam Berbagai Pembacaan Kontemporer. Yogyakarta: Pustaka Pelajar, 2009.

Kaelan, M.S. Metode Penelitian Agama: Kualitatif Interdisipliner. Yogyakarta: Paradigma, 2010.

Lee, Robert D. Mencari Islam Autentik: Dari Nalar Puitis Iqbal Hingga Nalar Kritis Arkoum. transl. Ahmad Baiquni. Bandung: Mizan, 2000.

Madjid, Nurcholish. Cita-cita Politik Islam Era Reformasi. Jakarta. Paramadina, 1999.

---------. Islam, Dotrin, dan Peradaban. Jakarta: Paramadina, 1992.

---------. Kaki Langit Peradaban Islam. Jakarta: Paramadina, 1997.

Mahendra, Yusril Ihza. Modernisme dan Fundamentalisme Dalam Politik Islam. Jakarta: Paramadina, 1999. 
Majelis Pertimbangan Pusat PKS. Platform Kebijakan Pembangunan Partai Keadilan Sejahtera. Jakarta: Majelis Pertimbangan Pusat PKS, 2007.

Mughni, Syafiq A. Nilai-nilai Islam: Rumusan, Ajaran, dan Aktualisasi. Yogyakarta: Pustaka Pelajar, 2001.

Mujiburahman. Mengindonesiakan Islam: Representasi dan Ideologi. Yogyakarta: Pustaka Pelajar, 2008.

Mulkhan, Abdul Munir. "Sendang Ayu: Pergulatan Muhammadiyah di Kaki Bukit Barisan.” Suara Mubammadiyah, 2 January 2006.

Mustari. "Etika Religius Syekh Yusuf, Relevansinya Dengan Dakwah Islam di Indonesia." Unpublished Doctoral Thesis, Yogyakarta, Gajah Mada University, 2009.

Muzadi, Hasyim et al. Gerakan Radikal Islam di Indonesia dalam Sorotan. Jakarta: ASEAN Youth and Student Network, 2004.

Peacock, James L. Muslim Puritans: Reformis Psycology in South East Asian Islam. Barkeley: University of California Press, 1978.

Rahman, Fazlur. "Islam: Challenges and opportunity." in Alford T. Welch and Pierra Cachia (ed.). Islam, Past Influence and present Chalenge. Edinburgh: Edinburgh University, 1979.

--------. Gelombang Perubahan dalam Islam: Studi tentang Fundamentalisme Islam. Jakarta: Rajawali Press, 2000.

Sidahmed, Absel Salam and Anoushiravan Ehteshami. Islamic Fundamentalism. Colorado: Westview, 1996.

The WAHID Institute, "Pluralisme Beragama/Berkeyakinan di Indonesia: Menapaki bangsa yang Kian Retak", 2008, at URL: http://www.WahidInstitute.org/files/docs-/laporan Pluralisme 2008 WahidInstitute.pdf

Tibi, Bassam. Ancaman Fundamentalisme: Rajutan Islam Politik dan Kekacauan Dunia Baru. Yogyakarta: Tiara Wacana, 2000.

Wahid, Abdurrahman (ed.). Islam, Negara dan Demokrasi. Jakarta: Erlangga, 1999.

--------. Mengurai Hubungan Agama dan Negara. Jakarta: Grasindo, 1999.

Watt, William Montgomery. Fundamentalisme Islam dan Modernitas. Jakarta: PT. Rajagrafido Persada, 1997.

Zastrouw. Gerakan Islam Simbolik. Yogyakarta: LKiS, 2007. 